\title{
Metalloproteinase Inhibitor 1
}

National Cancer Institute

\section{Source}

National Cancer Institute. Metalloproteinase Inhibitor 1. NCI Thesaurus. Code C17543.

Metalloproteinase inhibitor 1 (207aa, $28 \mathrm{kDa}$ ) is encoded by the human TIMP1 gene.

This protein is involved in both erythropoiesis and metalloproteinase inhibition. 